Jurnal

Kardiologi Indonesia

J Kardiol Indones. 2013;34:160-6

ISSN $0126 / 3773$

Clinical Research

\title{
Differences of Serum Ratio MMP-9/TIMP- 1 in ST-Elevation Myocardial Infarction (STEMI) and Non ST-Elevation Acute Coronary Syndrome (NSTEACS)
}

\author{
Basuki Rahmat*, Lucia Kris Dinarti**, Irmalita***, Budi Yuli Setianto**
}

Department of Cardiology and Vascular Medicine, Faculty of Medicine, University of Mataram
Background: Differences between the pathogenesis of ST-Elevation Myocardial infarction (STEMI) and Non-ST Elevation Acute Coronary Syndrome (NSTE-ACS) had yet unknown. Matrix metalloproteinase-9 (MMP-9) as the matrix degradation enzyme secreted by inflammatory cells play a role in the pathogenesis of plaque rupture. MMP-9 proteolytic activity is inhibited by specific inhibitors of the Tissue Inhibitor of metalloproteinase-I (TIMP-I). MMP-9/TIMP-I ratio describes the actual proteolytic activity of MMP-9. This ratio may distinguish the pathogenesis of STEMI and NSTE-ACS. Objective: To examine the difference serum level ratio MMP-9/TIMP-I in patients with STEMI and NSTE-ACS.

Methods and subjects: This is a cross-sectional study which recruits patients consecutively with ACS admitted to ICCU of Dr. Sardjito General Hospital Yogyakarta within $24 \mathrm{~h}$ onset. Acute infection, chronic inflammation, acute stroke, kidney failure requiring renal replacement therapy, chronic heart failure, liver cirrhosis, acute exacerbation of COPD and pneumonia, thromboembolic disease, malignancy, pregnancy and the use of steroids and steroid anti-inflammatory drugs are excluded. Serum levels of MMP-9 and TIMP-I examined using the method of sandwich enzyme-linked immunosorbent assay (ELISA).

Results: The total of 60 subjects with STEMI patients $3 \mathrm{I}$ (5I.7\%) and NSTEACS $29(48.3 \%)$. Level of serum MMP-9/TIMP-I ratio is significantly higher in STEMI compared to NSTE-ACS (I.I $06 \pm 0.065$ vs. I.046 $\pm 0.057, p<0.00 I)$. MMP-9/TIMP-I ratio in serum is an independent factor for STEMI $(p=0.003)$ followed by blood sugar level $(p=0.013)$ and MMP-9 $(p=0.033)$. Interestingly, patients with serum MMP-9/TIMP-I ratio > I.0639 has a prevalence risk of I.7 times having STEMI ( $p=0.039$; KI95\% from I .040 to 8.508). Levels of serum MMP-9/TIMP-I ratio significantly higher in STEMI compared to NSTEMI group $(p=0.003)$ and in the STEMI and UAP group (0.026), but did not differ significantly in NSTEMI and UAP group $(p=0.045)$.

Conclusion: High levels of serum MMP-9/TIMP-I ratio in patients with STEMI than NSTEACS may explain the role of serum MMP-9/TIMP-I ratio in differentiating the pathogenesis of STEMI and NSTE-ACS.

(J Kardiol Indones. 2013;34:160-6)

Keywords: The ratio of MMP-9/TIMP- I; ST-Elevation Myocardial infarct; Non-ST Elevation Acute Coronary Syndrome. 
Jurnal

\title{
Perbedaan Rasio Kadar Serum MMP-9/TIMP- 1 pada Kejadian Infark Miokard Akut Elevasi Segmen ST (IMA-EST) dan Sindroma Koroner Akut Non Elevasi Segmen-ST (SKA-NEST)
}

\author{
Basuki Rahmat*, Lucia Kris Dinarti**, Irmalita***, Budi Yuli Setianto**
}

\begin{abstract}
Latar Belakang: Perbedaan antara patogenesis Infark miokard akut elevasi segmen ST (IMA-EST) dan Sindroma koroner akut non elevasi segmen ST (SKA-NEST) sampai saat ini belum jelas. Matrix Metalloproteinase-9 (MMP-9) sebagai enzim degradasi matrik yang disekresikan oleh berbagai sel inflamasi berperan dalam patogenesis ruptur plak. Aktivitas proteolitik MMP-9 dihambat oleh inhibitor spesifiknya yaitu Tissue Inhibitor Metalloproteinase-1 (TIMP-1). Rasio MMP-9/TIMP-1 menggambarkan aktivitas proteolitiknya MMP-9 sebenarnya. Rasio ini mungkin membedakan patogenesis IMA-EST dan SKA-NEST. Akan tetapi, sampai saat ini belum ada studi yang membandingkan rasio kadar serum MMP-9/TIMP-1 pada pasien IMA-EST dan SKA-NEST.

Tujuan: untuk mengetahui perbedaan rasio kadar serum MMP-9/TIMP-1 pada pasien IMA-EST dan SKA-NEST.

Subjek dan metode penelitian: penelitian ini merupakan studi potong lintang dengan pengambilan sampel penelitian secara konsekutif pada pasien sindroma koroner akut (SKA) yang dirawat di Intensive Coronary Care Unit (ICCU) dalam waktu 24 jam onset. Pasien infeksi akut, inflamasi kronik, stroke akut, gagal ginjal yang membutuhkan terapi pengganti ginjal, gagal jantung kronik, sirosis hepatis, PPOK eksaserbasi akut dan pneumonia, penyakit tromboemboli, keganasan, kehamilan dan penggunaan steroid dan obat anti inflamasi bukan steroid dieksklusi. Kadar serum MMP-9 dan TIMP-1 diperiksa dengan metode sandwich enzyme-linked immunosorbent assay (ELISA).

Hasil: Total subjek penelitian sebanyak 60 pasien SKA dengan IMA-EST 31 (51,7\%) dan SKA-NEST 29 (48,3\%). Rasio kadar serum MMP-9/TIMP-1 lebih tinggi bermakna pada IMA-EST dibandingkan SKA-NEST (1,106 $\pm 0,065$ vs 1,046 $\pm 0,057$; $\mathrm{p}<0,001)$. Rasio kadar serum MMP-9/TIMP-1 merupakan faktor independen untuk IMA-EST ( $\mathrm{p}=0,003)$ diikuti gula darah sewaktu ( $\mathrm{p}=0,013)$ dan MMP-9 ( $\mathrm{p}=0,033)$. Menariknya, pasien dengan rasio kadar serum MMP-9/TIMP-1 >1,0639 memiliki risiko prevalensi 1,7 kali terjadi IMA-EST ( $\mathrm{p}=0,039 ; \mathrm{KI} 95 \%$ 1,040-8,508). Rasio kadar serum MMP-9/TIMP-1 lebih tinggi bermakna pada kelompok IMA-EST dibandingkan IMA-NEST ( $\mathrm{p}=0,003)$ dan pada kelompok IMA-EST dan Angina pektoris tidak stabil (APTS) (0,026), tapi tidak berbeda bermakna pada kelompok IMA-NEST dan APTS ( $\mathrm{p}=0,045)$.

Kesimpulan: Tingginya rasio kadar serum MMP-9/TIMP-1 pada pasien IMA-EST dibandingkan SKA-NEST mungkin menjelaskan peran rasio kadar serum MMP-9/TIMP-1 dalam membedakan patogenesis IMA-EST dan SKA-NEST.
\end{abstract}

(J Kardiol Indones. 2012;33:160-6)

Kata kunci: Rasio MMP-9/TIMP-1; Infark miokard akut elevasi segmen ST; Sindroma koroner akut non elevasi segmen ST.

\begin{abstract}
Alamat Korespondensi
dr. Basuki Rahmat, SpJP, Bagian Kardiologi dan Kedokteran Vaskular

Fakultas Kedokteran Universitas Mataram. Lombok Barat, NTB.

No telp: 0370-648478, No Hp: 08|804006/4I/08|392329555.

E-mail: rahmatmataram0I@gmail.com
\end{abstract}


Jurnal Kardiologi Indonesia

\section{Pendahuluan}

Sindroma koroner akut (SKA) merupakan manifestasi iskemia miokard akut. Terdapat perbedaan patogenesis terjadinya infark miokard akut dengan elevasi segmen ST (IMA-EST) dan sindroma koroner akut non elevasi segmen ST (SKA-NEST). Patogenesis SKA-NEST ditandai dengan adanya trombus yang menyebabkan obstruksi sebagian yang dapat mengakibatkan iskemi atau infark miokard lokal. Sedangkan pada IMA-EST, trombus tersebut menyebabkan obstruksi total pada arteri koroner yang mengalami ruptur yang mengakibatkan infark miokard transmural. ${ }^{1}$

Berbagai penelitian telah dilakukan untuk mengetahui patogenesis aterosklerosis, salah satunya adalah proses inflamasi. Inflamasi pada dinding pembuluh darah memiliki peran dalam pembentukan plak aterosklerosis, instabilisasi plak, hingga terjadinya ruptur plak pada SKA. Koenig dan Khuseyinova dalam tulisannya menyebutkan sejumlah biomarker inflamasi yang berhubungan dengan instabilitas plak, salah satunya adalah Matrix metalloproteinase (MMP). ${ }^{2}$ Matrix metalloproteinase merupakan suatu enzim yang berfungsi dalam mendegradasi matrik ekstraseluler pada fibrous cap plak yang kaya kolagen. Kemampuannya inilah yang berperan dalam destabilisasi plak terutama pada SKA. Matrix metalloproteinase-9 merupakan salah satu MMP yang mempunyai peran penting pada SKA. ${ }^{3,4,5}$ Inhibitor endogen MMP yaitu Tissue Inhibitor Matrix Metalloproteinase (TIMP) memiliki aktivitas dalam menghambat degradasi matriks ekstraseluler oleh MMP. TIMP-1 merupakan TIMP yang poten dalam menghambat aktivitas proteolitik MMP-9.5

Keseimbangan MMP dan TIMP menentukan aktivitas proteolitik sebenarnya dari MMP dan mengontrol degradasi matrik ekstraseluler. ${ }^{6}$ Keseimbangan MMP dan TIMP mempunyai peran penting dalam pemecahan fibrous cap plak yang selanjutnya menyebabkan ruptur plak. Rasio MMP-9/TIMP-1 menunjukkan peningkatan yang bermakna pada IMAEST dibandingkan kontrol sehat, ${ }^{7}$ dan rasio MMP-9/ TIMP-1 juga mengalami peningkatan yang bermakna pada SKA dibandingkan kontrol sehat. ${ }^{6}$ Kedua penelitian tersebut hanya menjelaskan perbedaan bahwa pada SKA ataupun IMA-EST memiliki rasio MMP-9/TIMP-1 yang tinggi dibanding kontrol. Kedua penelitian tersebut belum dapat menjelaskan mengapa pada seseorang yang memiliki faktor risiko yang sama dapat terjadi IMA-EST sedangkan yang lain terjadi SKA-NEST. Hingga saat ini, belum ada penelitian yang dapat menjelaskan faktor-faktor yang berpengaruh terhadap perbedaan patogenesis antara IMA-EST dan SKA-NEST. Penelitian ini mencoba mengetahui apakah perbedaan rasio kadar serum MMP-9/TIMP-1 merupakan faktor yang berpengaruh terhadap perbedaan patogenesis IMA-EST dan SKANEST.

\section{Subjek Dan Metoda}

Rancangan penelitian ini adalah potong lintang dengan pengambilan sampel secara berurutan (consecutive sampling). Kriteria inklusi penelitian ini adalah pasien dengan diagnosis IMA-EST baik yang dilakukan reperfusi (PCI maupun trombolisis) ataupun tidak dan SKA-NEST yang meliputi IMA-NEST dan angina tak stabil dengan onset serangan pada kedua kelompok < $24 \mathrm{jam}$. Kriteria eksklusi penelitian ini meliputi infeksi akut, inflamasi kronik, stroke akut, gagal ginjal yang membutuhkan terapi pengganti ginjal, gagal jantung kronik, sirosis hepatis, PPOK eksaserbasi akut dan pneumonia, penyakit tromboemboli, keganasan, kehamilan dan penggunan steroid dan obat anti inflamasi bukan steroid.

Diagnosis IMA-EST dan SKA-NEST ditetapkan berdasarkan kriteria diagnosis yaitu nyeri dada yang khas, gambaran EKG 12 sadapan dan kadar enzim CKMB dan troponin I. Pengambilan sampel MMP-9 dan TIMP-1 menggunakan serum darah perifer pada posisi pasien supine. Sampel diambil dengan vacutainer, dibiarkan menggumpal dan disimpan pada suhu $4^{\circ} \mathrm{C}$ di dalam freezer, kemudian sampel segera dikirim ke laboratorium Prodia untuk dilakukan sentrifugasi $2500 \mathrm{rpm}$ dalam 10 menit dan disimpan pada suhu - 80 C hingga saat akan dilakukan pemeriksaan. Pemeriksaan MMP-9 dilakukan dengan standar metode ELISA (Quantikine ${ }^{\circledR}$ Human MMP-9 Total Immunoassay (R\&D Systems)) dan untuk TIMP-1 juga menggunakan metode ELISA (Quantikine ${ }^{\circledR}$ Human TIMP-1 Immunoassay (R\&D Systems)) di laboratorium Prodia Pusat Jakarta.

Penelitian ini telah mendapatkan persetujuan dari Komite Etik Fakultas Kedokteran, Universitas Gadjah Mada. Subjek memberikan informed consent untuk pengambilan sampel serum guna pemeriksaan laboratorium dan partisipasi dalam penelitian. 


\section{Hasil}

\section{Karakteristik Subyek Penelitian Kelompok IMA-EST dan SKA-NEST}

Analisis penelitian ini menunjukkan angka leukosit yang lebih tinggi secara bermakna pada kelompok IMA-EST dibandingkan kelompok SKA-NEST $(11,68 \pm 3,88$ vs $9,54 \pm 3,42 ; \mathrm{p}=0,01)$. Hasil sub analisis korelasi Spearman antara lekosit dan MMP-9 yang menunjukkan lekosit dan MMP-9 memiliki korelasi positif lemah $(r=0,29 ; p=0,027)$. Kadar gula darah sewaktu yang diperiksa saat pasien pertama kali masuk rumah sakit lebih tinggi secara bermakna pada kelompok IMA-EST dibandingkan kelompok SKA$\operatorname{NEST}(205,8 \pm 8$ vs $145 \pm 96,3 ; \mathrm{p}=0,003)$.

\section{Kadar MMP-9 dan TIMP-I pada IMA-EST dan SKA-NEST}

Kadar MMP-9 pada kelompok IMA-EST lebih tinggi secara bermakna dibandingkan kelompok SKANEST $(124,74 \pm 69,8$ vs $1216,8 \pm 833,3 ; p=0,026)$. Kadar TIMP-1 pada studi ini tidak bermakna antara kelompok IMA-EST dan SKA-NEST $(\mathrm{p}=0,05)$.

\section{Rasio MMP-9/TIMP-I sebagai faktor risiko bebas kejadian IMA-EST dan SKA-NEST}

Rasio MMP-9/TIMP-1 pada kelompok IMA-EST lebih tinggi secara bermakna dibandingkan kelompok SKA-NEST $(1,106 \pm 0,065$ vs $1,046 \pm 0,057 ; \mathrm{p}<0,001$; KI95\% 0,03-0,09). (Gambar 1)

Tabel 1. Analisis bivariat karakteristik dasar pasien SKA

\begin{tabular}{|c|c|c|c|c|}
\hline Variabel & $\begin{array}{l}\text { IMA-EST } \\
(31)\end{array}$ & $\begin{array}{l}\text { SKA-NEST } \\
(29)\end{array}$ & Nilai $p$ & IK $95 \%$ \\
\hline \multicolumn{5}{|l|}{ Jenis kelamin } \\
\hline Laki-laki & $28(56 \%)$ & $22(44 \%)$ & 0,13 & \\
\hline Perempuan & $3(30 \%)$ & $7(69 \%)$ & & \\
\hline Usia (tahun)* & $55,6 \pm 7,2$ & $54,4 \pm 7,2$ & 0,55 & \\
\hline \multicolumn{5}{|l|}{ Faktor risiko } \\
\hline - Diabetes melitus & $8(72,7 \%)$ & $3(27,3 \%)$ & 0,12 & \\
\hline - Hipertensi & $13(40,6 \%)$ & $19(59,4 \%)$ & 0,07 & \\
\hline - Merokok & $19(54,3 \%)$ & $16(45,7 \%)$ & 0,63 & \\
\hline - Dislipidemia & $10(50 \%)$ & $10(50 \%)$ & 0,85 & \\
\hline Onset $(\mathrm{jam})^{*}$ & $8,06 \pm 5,5$ & $9,33 \pm 7,04$ & 0,67 & \\
\hline Skor Killip & & & 0,51 & \\
\hline Killip klas I & $20(48,8 \%)$ & $21(51,2 \%)$ & & \\
\hline Killip klas II-IV & $11(57,9 \%)$ & $8(42,1 \%)$ & & \\
\hline \multicolumn{5}{|l|}{ Hasil laboratorium } \\
\hline Hemoglobin (g/dl) & $13,97 \pm 1,29$ & $14,6 \pm 1,56$ & 0,10 & $-1,35-0,13$ \\
\hline Angka leukosit (ribu/mmk)* & $11,68 \pm 3,88$ & $9,54 \pm 3,42$ & 0,01 & \\
\hline Angkatrombosit(ribu/mmk) & $244,2 \pm 78,6$ & $232 \pm 68,1$ & 0,52 & $-26,3-50,5$ \\
\hline Kreatinin $(\mathrm{mg} / \mathrm{dl})^{*}$ & $1,36 \pm 0,47$ & $1,18 \pm 0,31$ & 0,14 & \\
\hline Gula darah sewaktu $(\mathrm{mg} / \mathrm{dl})^{*}$ & $205,8 \pm 112,3$ & $145 \pm 96,3$ & 0,003 & \\
\hline Kolesterol total $(\mathrm{mg} / \mathrm{dl})^{*}$ & $197,3 \pm 61,7$ & $197,8 \pm 42,9$ & 0,96 & $-28,2-27,1$ \\
\hline Kolesterol LDL (mg/dl)* & $147,9 \pm 44,8$ & $141,4 \pm 40,1$ & 0,59 & \\
\hline Kolesterol HDL (mg/dl)* & $37,4 \pm 9,8$ & $37,7 \pm 8,7$ & 0,96 & \\
\hline Trigliserida $(\mathrm{mg} / \mathrm{dl})^{*}$ & $124,74 \pm 69,8$ & $131,86 \pm 78,1$ & 0,74 & \\
\hline MMP-9* & $1628,3 \pm 676,4$ & $1216,8 \pm 833,3$ & 0,026 & \\
\hline TIMP-1* & $1483,3 \pm 638,4$ & $1164,7 \pm 798,9$ & 0,05 & \\
\hline MMP-9/TIMP-1 & $1,106 \pm 0,065$ & $1,046 \pm 0,057$ & $<0,001$ & 0,03-0,09 \\
\hline
\end{tabular}

Keterangan: SKA: Sindroma koroner akut; LDL: Low density lipoprotein; HDL: High density lipoprotein; CKMB: Creatin kinase-MB; MMP-9: Matrix metalloproteinase-9; TIMP-1: Tissue inhibitor matrix metalloproteinase-1. *Mannwhitney test 


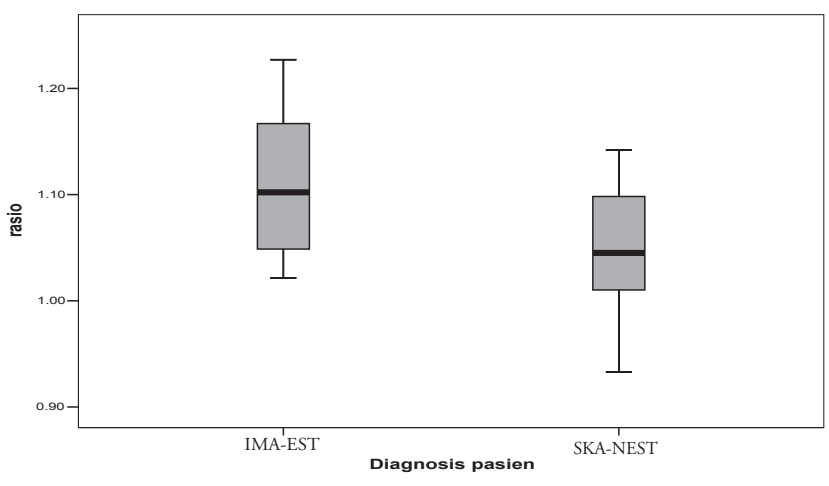

Gambar 1. Grafik box plot perbedaan rerata rasio MMP-9/ TIMP-1 pada IMA-EST dan SKA-NEST.

Analisis multivariat menunjukkan bahwa rasio MMP-9/TIMP-1 merupakan faktor bebas $(\mathrm{p}=0,003)$ diikuti gula darah sewaktu $(\mathrm{p}=0,013)$ dan MMP-9 $(\mathrm{p}=0,033)$ terhadap kejadian IMA-EST dan SKANEST, sedangkan angka lekosit bukan merupakan faktor bebas kejadian IMA-EST dan SKA-NEST $(\mathrm{p}=0,628)$.

\section{Proporsi Kejadian IMA-EST Berdasarkan Nilai Cut off Rasio MMP-9/TIMP-I}

Rasio MMP-9/TIMP-1 pada studi-studi sebelumnya belum ditetapkan nilai cut-off-nya sebagai alat diagnostik. Walaupun studi ini tidak bermaksud untuk menetapkan rasio MMP-9/TIMP-1 sebagai alat diagnostik, tetapi analisis kurva ROC pada studi diharapkan dapat membantu peneliti dalam menentukan perbedaan proporsi dan risiko prevalensi

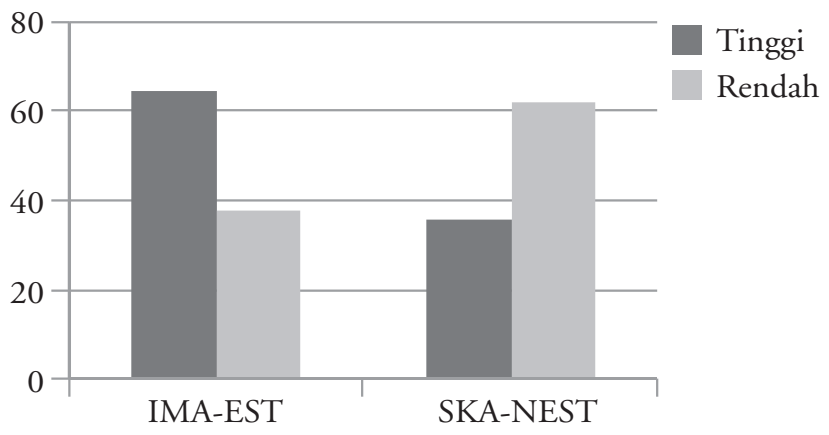

Gambar 2. Grafik batang perbedaan proporsi rasio MMP-9/ TIMP-1 terhadap kejadian IMA-EST dan SKA-NEST. rasio MMP-9/TIMP-1 pada kejadian IMA-EST dan SKA-NEST. Analisis kurva ROC rasio MMP-9/ TIMP-1 menunjukkan nilai cut-off 1,0639 dengan sensitifitas 64,5\%, spesifitas $62,1 \%$ dan AUC 74,1 $\%$. Nilai cut-off rasio MMP-9/TIMP-1 dibawah atau sama dengan 1,0639 ditetapkan sebagai rasio rendah dan nilai cut-off lebih dari 1,0639 ditetapkan sebagai rasio tinggi. Analisis chi-square menunjukkan proporsi rasio MMP-9/TIMP-1 lebih tinggi secara bermakna pada kelompok IMA-EST dibandingkan kelompok SKA-NEST ( $\mathrm{p}=0,039$; IK95\% 1,040-8,508). Rasio MMP-9/TIMP-1 tinggi memiliki risiko prevalensi 1,7 kali terhadap kejadian IMA-EST (Gambar 2).

\section{Diskusi}

Penelitian ini menilai peranan rasio kadar serum MMP-9/TIMP-1 sebagai pembeda patogenesis IMA-EST dan SKA-NEST. Beberapa penelitian terdahulu diawali oleh Kai dkk tahun 1998 yang melaporkan adanya peningkatan kadar MMP-9 pada pasien SKA sampai studi Cheng dkk tahun 2008 yang telah membahas rasio MMP-9/TIMP-1 pada pasien SKA.

Pada studi terdahulu tersebut, Ferroni $\mathrm{dkk}^{3}$ dan Kai $\mathrm{dkk}^{8}$ tidak mengikutsertakan TIMP-1 sebagai salah satu marker yang diteliti pada SKA. Sedangkan Manginas $\mathrm{dkk}^{9}$ telah menilai MMP-9 dan TIMP-1 pada SKA pada kelompok IMA-NEST, APTS dan kontrol sehat tetapi tidak menganalisis rasio kadar serum MMP-9/TIMP-1 sebagai variabel dalam SKA. Penelitian yang menganalisis perbedaan rasio kadar serum MMP-9/TIMP-1 pada SKA adalah Cheng $\mathrm{dkk}^{6}$ dan Tan $\mathrm{dkk} .^{7}$ Akan tetapi kedua studi tersebut berbeda dalam hal populasi penelitian dibandingkan penelitian yang dilakukan penulis. Studi Tan $\mathrm{dkk}^{7}$ melibatkan kelompok IMA-EST dan kontrol sehat sedangkan Cheng $\mathrm{dkk}^{6}$ melibatkan kelompok SKA, APS dan kontrol sehat. Sehingga kedua studi tersebut belum dapat menjelaskan perbedaan parogenesis antara IMA-EST dan SKA-NEST.

Kadar TIMP-1 pada studi ini tidak bermakna antara kelompok IMA-EST dan SKA-NEST $(\mathrm{p}=0,05)$. Hasil ini sesuai dengan Manginas $\mathrm{dkk}^{9}$ dan Inokubo $\mathrm{dkk}^{10}$ yang mendapatkan TIMP-1 tidak meningkat bermakna pada SKA dibandingkan APS. Kadar TIMP1 yang tidak berbeda bermakna antara kedua kelompok kemungkinan disebabkan oleh median onset subyek penelitian ini masih awal yaitu jam ke-6 dari onset 
SKA. Thompson ${ }^{11}$ mengungkapkan bahwa TIMP-1 berperan untuk menghambat proteolitik MMP-9 dan untuk peningkatannya membutuhkan waktu yang lebih lama dibandingkan MMP-9. Romanic $\mathrm{dkk}^{12}$ menyatakan bahwa TIMP-1 mulai meningkat setelah SKA, tapi mulai jam ke berapa setelah SKA belum dapat disimpulkan. Walaupun TIMP-1 telah terbukti sebagai inhibitor MMP-9, akan tetapi TIMP1 memiliki kelemahan dimana TIMP-1 tidak dapat menghambat aktivitas MMP-2 dan MT1-MMP. Hal ini dapat menjadi salah satu alasan mengapa pada studi ini, kelompok IMA-EST memiliki kadar TIMP-1 yang cenderung lebih tinggi dibanding kelompok SKA-NEST.

Hasil studi ini menunjukkan rasio MMP-9/TIMP1 lebih tinggi secara bermakna pada kelompok IMAEST dibandingkan SKA-NEST. Analisis multivariat juga menunjukkan bahwa rasio MMP-9/TIMP-1 merupakan faktor risiko bebas diikuti kadar gula darah sewaktu dan kadar MMP-9 terhadap kejadian IMAEST dan SKA-NEST. Cheng $\mathrm{dkk}^{6}$ menyimpulkan bahwa rasio MMP-9/TIMP-1 dan adiponektin merupakan faktor risiko independen terhadap kejadian IMA-EST.

Keterbatasan penelitian ini antara lain faktor-faktor perancu lain yang kemungkinan berperan terhadap kejadian IMA-EST dan SKA-NEST seperti sitokin inflamasi, tissue factor, kolateral koroner tidak dinilai. Pemeriksaan biomarker baik MMP-9 dan TIMP-1 tidak dilakukan serial sehingga tidak diketahui kadar puncaknya. Kemungkinan adanya perubahan struktur protein pada biomarker yang disebabkan sampel diperiksa setelah keseluruhan sampel terkumpul walaupun penyimpanan sampel telah dilakukan sesuai dengan protokol.

\section{Kesimpulan}

Rasio kadar serum MMP-9/TIMP-1 lebih tinggi bermakna pada IMA-EST dibandingkan SKANEST.

Perlu dilakukan penelitian dengan disain cohort sehingga faktor-faktor lain yang mempengaruhi tingginya rasio kadar serum MMP-9/TIMP-1 dan faktor perancu lain terhadap kejadian IMA-EST dan SKA-NEST dapat dikendalikan. Perlu dilakukan suatu penelitian prognostik untuk menilai kemampuan rasio kadar serum MMP-9/TIMP-1 dalam memprediksi luaran setelah IMA-EST dan SKA-NEST.

\section{Daftar Pustaka}

1. Ryan, T.J., Antman, E.M., Brooks, N.H., Califf, R.M., Hillis, L.D., Hiratzka, L.F., et al.Update: ACC/AHA guidelines for the management of patients with acute myocardial infarction. A report of the American College of Cardiology/American Heart Association Task Force on Practice Guidelines. J Am Coll Cardiol, 1999;34:890 -911.

2. Koenig, W., Khuseyinova, N. Biomarkers of Atherosclerotic Plaque Instability and Rupture. Arterioscler. Thromb. Vasc. Biol. 2007;27:15-26.

3. Ferroni, P., Basili, S., Martini. F., Cardarello, C. M., Ceci, F., Di Franco, M., Bertazzoni, G., Gazzaniga, P. P., Alessandri, C. Serum metalloproteinase 9 levels in patients with coronary artery disease: a novel marker of inflammation. J Investig Med., 2003; 51(5):295-300.

4. Yan, J. C., Wu, Z, G., Kong, X. T., Zong, R. Q., Zhan, L. Z. Relation between upregulation of CD40 system and compelx stenosis morphology in patients with acute coronary sysdrome. Acta Pharmacol Sin. 2004; 25(2):251-256.

5. Newby, A. Dual Role of Matrix Metalloproteinases (Matrixins) in Intimal Thickening and Atherosclerotic Plaque Rupture. Physiol Rev, 2005;85:1-31.

6. Cheng,M., Hashmi, S., Mao, X., Zeng, Q.T. Relationships of adiponectin and matrix metalloproteinase- 9 to tissue inhibitor of metalloproteinase-1 ratio with coronary plaque morphology in patients with acute coronary syndrome. Can J Cardiol. 2008; 24(5):385-390

7. Tan, J., Hua, Q., Gao, J., Fan, Z. X. Clinical Implications of Elevated Serum Interleukin-6, Soluble CD40 Ligand, Metalloproteinase-9, and Tissue Inhibitor of Metalloproteinase-1 in Patients with Acute ST-segment Elevation Myocardial Infarction. Clin. Cardiol. 2008;31(9):413-418.

8. Kai, H., Ikeda, H., Yasukawa, H., Kai, M., Seki, Y., Kuwahara, F., Ueno, T., Sugi, K., Imaizumi, T. Peripheral blood levels of matrix metalloproteases- 2 and -9 are elevated in patients with acute coronary syndromes. J Am Coll Cardiol, 1998;32(2):368-372.

9. Manginas, A., Bei, E., Chaidaroglou, A., Degiannis, D., Koniaviaton, K., Voudris, V., Pavlides, G., Panagiotakos, D., Cokkinos, D.V. Peripheral levels of matrix metalloproteinase-9, interleukin-6, and C-reactive protein are elevated in patients with acute coronary syndromes: correlations with serum troponin I. Clin Cardiol. 2005;28(4):182-186.

10. Inokubo, Y., Hanada, H., Ishizaka, H., Fukushi, T., Kamada, T., Okumura, K.Plasma levels of matrix metalloproteinase-9 and tissue inhibitor of metalloproteinase- 1 are increased in the coronary circulation in patients with acute coronary syndrome. Am Heart J. 2001;141:211-7.

11. Thompson, M.M., Squire, I.B. Matrix metalloproteinase-9 expression after myocardial infarction: physiological or 
pathological?. Cardiovascular Research. 2002;54:495-498

12. Romanic, A.M., Harrison, S.M., Bao, W., Burns-Kurtis, C.L., Pickering, S., Gu, Garu, E., Mao, J., Sathe, G.M., Ohlstein, E.H., Yue, T.L. Myocardial protection from ischemia/ reperfusion injury by targeted deletion of matrix metalloproteinase-9. Cardivascular Research. 2002;54:549-558

13. Holven K.B., Aukrust, P., Pedersen, T.M., Ose, L., Nenseter,
M.S. Enhanced Platelet Activation In Hyperhomocysteinemic Individuals, Journal of Thrombosis and Haemostasis. 2006. Volume 5, Issue 1, pages 193-195

14. Libby, P.The Vascular Biology of Atherosclerosis. In Zipes, D.P., Libby, P., Bonow, R.O., Braunwald, E (ed.), Braunwald's Heart Disease: A Textbook os Cardiovascular Medicine. 2006.Elseviern Saunders, Vol. 2: pp. 921-958. 